International Journal of Engineering \& Technology, 7 (3.9) (2018) 93-99
International Journal of Engineering \& Technology
SPC
Website: www.sciencepubco.com/index.php/IJET
Research paper

\title{
Ecological Urbanism in the Tropics Studies on the Sustainable Dimensions of Malay Traditional Urban Centers
}

\author{
Puteri Shireen Jahn Kassim Illyani Ibrahim Nor Zalina Harun Kamariah Kamaruddin \\ Associate Professor, Department of Applied Arts and Design, \\ Kulliyyah of Architecture and Environmental Design, \\ International Islamic University Malaysia, 53100 Kuala Lumpur, Malaysia \\ Assistant Professor, Department of Urban and Regional Planning, \\ Kulliyyah of Architecture and Environmental Design, \\ International Islamic University Malaysia, 53100 Kuala Lumpur, Malaysia \\ Associate Professor, Institute of the Malay World and Civilization (ATMA), \\ Universiti Kebangsaan Malaysia \\ PhD Candidate, Kulliyyah of Architecture and Environmental Design, \\ International Islamic University Malaysia, 53100 Kuala Lumpur, Malaysia. \\ *Corresponding author E-mail: Email: puterishr@iium.edu.my
}

\begin{abstract}
Many of the present eco-cities are designed and planned with an emphasis on high technology and infrastructure yet the meaning of sustainability itself implies a balance between past and present. Past urban configurations that rise from earlier traditional socio-cultural structures reflect sustainable principles localised to climate and ecology. The aim of this study is to reconstruct urban morphologies before the advent of the automobile in order to analyse and characterise urban forms that are aligned with ecological criteria such as walkability, permeability and shade. Three traditional urban center or 'cores' in tropical Malaysia which had reigned during the early colonial era yet still related sultanate-based polities are mapped in terms of morphologies and these urban 'core' configurations were estimated and composed according to historical documents and evidences. These urban patterns are then discussed with regards to the present principles and criteria of green urbanism. The reconstructed and mapped urban cores are discussed in relation to green urbanism principles and criteria, namely, based on global sustainable standards namely the LEED ND (Leadership in Energy and Environmental Design) version 4 neighbourhood rating system. The findings from this study suggest the contextualization of sustainable criteria according to climate and postulate the differences between traditional urban morphologies that can further regionalism principles of current green urbanism and further contextualise key principles in international standards on urbanism.
\end{abstract}

Keywords: sustainable urban form, tropical urbanism, green cities, topicality, Malay cities, tropical architecture, traditional urban morphology.

\section{Introduction}

The rise of sustainable development and its standards of assessment and ratings has induced scholars and planners to conceptualise and evolve new approaches and framework of redesigning the urban centers or developing urban centers from past models. Yet Hagan (2014) postulates the implications for cities and its designers - they are required to again address their metabolic as well as social and formal dimensions. She then explores the extent to which environmental engineering and natural systems design can and should become drivers for the remaking of cities in the 21 st century. Above all, she argues that sooner rather than later, urbanism needs to become environmentally literate, and environmental design needs to become culturally literate. Carmona (2010) similarly observes how recent developments in urban design have been concerned with 'an emerging tradition of sustainable urbanism' and cited Brown's et . al (2009) identification of the 'four convergent lines of thinking in sustainable urban- ism ..', and that is : 1)the need for vibrant walkable neighbourhoods that attract creative classes (ii) the emergence of downtowns of increasing demand for urban living; (iii) an awareness of the growing obesity which has spread due to car dependent urbanism; (iv) the growing interest in the potential of urban form to reduce the carbon footprint of mankind'. In relation to tropical South East Asia, Evers and Korff (2000) compares the stark differences between past and present urban forms in such tropical cities and highlights how past tradition forms once reflected the highly connected and legible patterns between city and other places by giving the example of connection between the center such as the palace, and the surrounding settlements and administrative districts. With respect to modernization and cities, Kusno (2010) highlights a phenomenon throughout Asia, during which in recent years, one sees the rising interest in urban history as a form of basis of contemporary urbanism. He observes that in new rapidly emerging cities such as in Indonesia, Thailand and Malaysia, developments are increasingly made of standalone parcels or "superblocks," i.e. in which large urban complexes consisting of residences, offices, shops, and entertainment venues, are devel- 
oped as islands surrounded by hard pavements or roads which only will excarbate the unsustainable conditions for the populations. Many observed how the local vernacular patterns does not seem to hold any lessons or principles. In relation to South East Asia, many centers of urban settlements, including those of the Malay region, had undergone a period of early 'modernity' during colonization, during which there is a complexity of functions and socio-political structures in the city, yet its related patterns still reflect 'quasi-urban' vernacular models. These hold containing sustainable principles as it was era in which low energy and low carbon models had predominated - whether in architecture or urban design - as functioning without excessive carbon emission was necessary throughout the city or urban core.

Amoroso (2014) offers suggestions that such early 'modernising' urban patterns, ,whether urban or cultural forms of early colonial period of Malaysia. were in fact, reflections of a range of symbolic traditionalism existences due to the dynamics of modern patterns brought in by the Colonialists and its subsequent impact of the socio-political and urban structures of the typical Malay town. It was a time when the reigning local socio-political systems was still influential, and these smaller cities and settlements still reflected the overall traditional planning, form, design and evolvement, while struggling with modern patterns of life and functions. It reflects, inherently, a balanced environmental pattern within which sustainability was an inherent principle as such urban centers grew. These patterns were fulfilling the demands of the communities and urbanisation yet they did not exert undue pressure of the surrounding ecological sensitivities. Shamsuddin (2014) has described the characteristic average pre-colonial Malay settlement as an organic pattern of growth where there is no clear geometric order presented.

The recent 'River of Life' redevelopment in the core of Kuala Lumpur, Malaysia, to the cost of 4 billion to the local government and urban development authority, has highlighted the costs of failing to grasp past traditional patterns of such patterns of the past which are crucial to sustainable targets of the future. It is only by investigating past urban grains and ecological credentials of past forms including environmental character of an urban core or city center that the immense historical, symbolic, social and environmental significance and including sustainable planning within traditional patterns can derive principles and prioritisation of criteria in arriving at low carbon cities locally. These traditional features or character include the relationship of urban grain and key ecological resources such as the river, sea or other water bodies, the relationship between public spaces and private structures, the figure-ground patterns of its urbanscape, the density around urban centers and the general integration of greenery and vistas; all which determine the character of a sustainable city.

Following on the heels of previous studies on the characteristics of the traditional urban centers, this study argues that during the early era of colonization, the functions of a 'modern city' is present, yet the patterns of the past is still intext. The impact of such urbanist yet 'vernacular' principles have been less researched and such urban 'patterns of language' ( Alexander, 1977) can be more persuasive than merely 'quantitative' requirements or 'numbers'. While traditional architecture forms, and features are known for its climatic and ecological criteria, a more in-depth look is needed on the urban centers of past models in the tropics in Asia, as such urban centers were 'modern' yet organic settlements evolving from past social structures of the local ruling elite, rooted in the feudal systems and polities of the $16^{\text {th }}$ century to the early phase of the 1900 s.

Thus, this paper aim to highlight the challenges in visualising such patterns through demonstrated morphologies, which can further shed light on patterns of urban design and urban landscape. By examining the historical patterns and character of urban area in the tropical settlements, the requirements of sustainability as stated at the current global principles of a green urbanism are highlighted in this study can be discussed in relation to the local context, an interest in low carbon cities highlights aspects that not only must satisfy present sustainable criteria; but must be adapted to the tropical context.

\section{Methodology}

To reconstruct and characterise the urban patterns of the traditional Malay and assess against the current sustainable urban development standards, a process of reconstruction was undertaken from literatures drawn from old planning reports, books and research articles in journals papers accessible through online databases. While historical data were assembled from old maps and photographs. Two historical Malay towns reigned by similar sultanate kingdom have been chosen as study area study. Melaka is located in the southern while Kuala Kangsar and Alor Setar are located in the northern part of Peninsular Malaysia. Using retracing and outlining current maps, visualising from textual and documentation evidences. Images, lithographs, textual and historical evidences are uncovered and studied including compilation of images and past photographs. Initially to reconstruct the first layer of these morphologies, satellite maps and later using Computer-Aided Design (CAD) tools, were used to locate public buildings and spaces. They were then modeled and detailed along key ecological elements of the settlement and urban centers such as greenery, rivers and key landscape elements.

\section{Results}

Results shows the overall morphology of the three cities. First$1 y$, the analysis of urban form and design in Melaka $\left(15^{\text {th }}\right.$ century), Kuala Kangsar (Perak)( 19 century) and Alor Setar $\left(19^{\text {th }}\right.$ century). Then, the similarities between the three urban core areas will be discussed in further.

\subsection{The $15^{\text {th }}$ century Melaka urban core}

Figure 1 represents the overall morphology of the 'port' city of Melaka and surrounding settlements as estimated using evidences from historical documents, lithographs and references. Amongst others, Temple(1928) describes the traveler 'Aroujo' who wrote 'one can possibly see at least 10, 000 houses which were situated along the coast and the river of Melaka. This description of Melaka is further enhanced by Giovanni who among other things mentioned; "the town is situated near the sea-shore and thickly strewn with houses and rooms, and it stretches for three leagues which is most beautiful to see...' Ancient Chinese documents of the 15th century which provide a glimpse into the settlements of the local inhabitants. In Harry Benda and John Larkin (eds.) (1967, p. 16) the port city, was described as clustering around a riverine settlement and patterns that reflect a feudal socio-economic system. The pattern is organic but mainly clustered around the main transportation route, the river, and clustering also occurs around the 'royal' palace which marks the domain and center of power. Figure 2 shows the $16^{\text {th }}$ century urban core morphology reflected the Malay socio-political structure 'the ruler was the center of the political system and the longevity of institution guarantee the longevity of the society' while the commercial zones are clustered near to the harbor. 


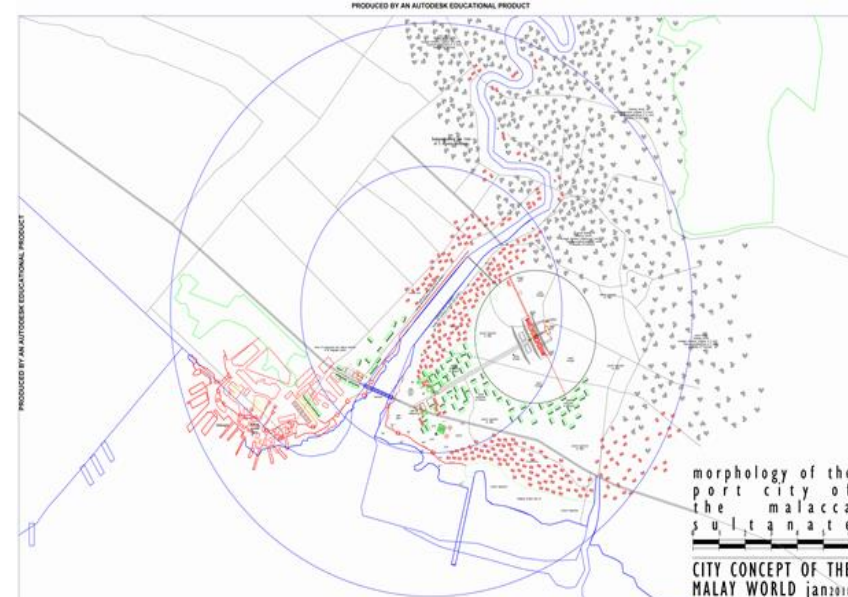

Figure 1. Overall estimated urban morphology of Melaka in the $15^{\text {th }}$ century - the pattern demonstrates the 'centrist' nature of the city and a densed clustering around the river as it was a main transportation node and commercial and social life of the times.



Figure 2. Melaka - a $16^{\text {th }}$ century projection of urban pattern configuration- a reconstruction from historical sources

In Figure 2, the estimated urban morphology shows the gateway to the port city of Kota Melaka (last strong hold of Melaka) linking the royal administrative city centre across the bridge to the commercial centre on the entreport side of the river bank. The bridge was estimated as masonry stonework below and timber above. A compact urban neighbourhood is estimated, with evidences pointing to a density of 7 to 12 unit's buildings per acre on the harbour side of the city comprising a mixed community of traders. A summary and estimation of some key components and elements of urban public spaces of the port city of Kota Melaka as reconstituted from past evidences is presented in Table 1, including from Portuguese lithographs.

Table 1 Urban space typologies and features extrapolated from the morphology of $16^{\text {th }}$ century Melaka urban core

\begin{tabular}{|l|l|}
\hline Urban public space & URBAN DESIGN AND PUBLIC SPACES \\
\hline Harbour & $\begin{array}{l}\text { Located on the northern side of the river bank } \\
\text { where the water is deep and suitable for a harbour. } \\
\text { Harbour facilities such as docks for ship repairs } \\
\text { and warehouses for storage of goods provided } \\
\text { under the control of 4 shahbandars (harbour princi- } \\
\text { ples for 4 category group of traders and a control } \\
\text { point for taxation } \\
\text { Entrepot commercial centre outside the fortified } \\
\text { city where trading take place in the open market or } \\
\text { the warehouse }\end{array}$ \\
\hline $\begin{array}{l}\text { Jetties on river } \\
\text { bank/ water front }\end{array}$ & $\begin{array}{l}\text { Perahu and sampan as river mode of transport for } \\
\text { goods and passengers into the hinterland and out to } \\
\text { the bigger ships anchored out at sea }\end{array}$ \\
\hline The Bridge & The gateway to the port city of Kota Melaka \\
\hline
\end{tabular}

\begin{tabular}{|c|c|}
\hline & $\begin{array}{l}\text { (the last strong hold of Malaka) linking the royal } \\
\text { administrative city centre across the bridge to the } \\
\text { commercial centre on the entrepot side of the river } \\
\text { bank. The bridge could have been of masonry } \\
\text { stonework below and timber above. }\end{array}$ \\
\hline $\begin{array}{l}\text { Commercial Centre } \\
\text { Pekan Cina } \\
\text { Bazaar Jawa }\end{array}$ & $\begin{array}{l}\text { Located right across the bridge, on the cosmopoli- } \\
\text { tan part of the city (on the northern side of the } \\
\text { river bank adjacent the harbour ) located within the } \\
\text { the mixed communities of } 84 \text { spoken languages of } \\
\text { non local residence lived }\end{array}$ \\
\hline Royal city Centre & $\begin{array}{l}\text { Located on the southern side of the river bank } \\
\text { with a breath taking hilltop backdrop and a } \\
\text { commanding view over the harbour and out to the } \\
\text { sea and the swampy coast occupied by fishermen } \\
\text { and orang laut who mainly served the Sultanate as } \\
\text { protectors of the whole stretch of the Selat Malaka } \\
\text { and with pedestrian lingkage to a public open space } \\
\text { the medan (court) where public can assemble }\end{array}$ \\
\hline $\begin{array}{l}\text { The Istana Com- } \\
\text { plex }\end{array}$ & $\begin{array}{l}\text { Prominent landmark location on the hill top for the } \\
\text { royal family comprises the complex of Istana } \\
\text { Besar, Istana Kecil, Balai Mengadap, Taman } \\
\text { Larangan/ Mandian ( the forbidden garden) panca } \\
\text { persada, bangsal gajah, and the open ground of } \\
\text { non hindering vista out to the sea and a line of site } \\
\text { to Bukit Cina }\end{array}$ \\
\hline \multicolumn{2}{|l|}{ BUILDINGS } \\
\hline Balai Hadapan & $\begin{array}{l}\text { The audience hall is of a courtyard concept to re- } \\
\text { ceive guest and dignitaries. It has balconies along } \\
\text { the front overlooking the courtyard and the view } \\
\text { beyond to the sea }\end{array}$ \\
\hline The Royal Mosque & located in the vicinity of the Balai Hadapan \\
\hline $\begin{array}{l}\text { Administrative Hall } \\
\text { and The Baitulmal } \\
\text { or storage centre }\end{array}$ & $\begin{array}{l}\text { Located beside the mosque, the administrative } \\
\text { centre managed the day to day running of the city } \\
\text { and managed the storage of the revenue collected } \\
\text { from trade taxes based on the Undang Undang } \\
\text { Kanun Melaka that is to be used in the running of } \\
\text { the harbour and public facilities and 'zakat' based } \\
\text { on 'syaria' law from the rich affordable Muslims } \\
\text { for redistribution to the needy poor. }\end{array}$ \\
\hline $\begin{array}{l}\text { Low Density Kam- } \\
\text { pung Neighbor- } \\
\text { hood }\end{array}$ & $\begin{array}{l}\text { Density of } 5 \text { to } 7 \text { units per acre located to the } \\
\text { southern side of the Malaka River within easy } \\
\text { access via foot path to the river transport to the } \\
\text { hinterland and to the harbour out to the sea }\end{array}$ \\
\hline $\begin{array}{l}\text { Compact Urban } \\
\text { Neighbouthood }\end{array}$ & $\begin{array}{l}\text { Density of } 7 \text { to } 12 \text { units per acre on the harbour } \\
\text { side of the city comprising a mixed community of } \\
\text { traders }\end{array}$ \\
\hline
\end{tabular}

\subsection{Kuala Kangsar (Perak)}

Kuala Kangsar in the late 1800 s can be described as a tension between precolonial and post-colonial era, reflecting similar urban patterns throughout the region, in which such patterns reflected the beginnings of the absorption and diffusion of primarily European influences. Unlike other Malay cities, Kuala Kangsar was built further inland, perhaps due to the repeated attacks from Acheh forces which emerged in the 17th century as a rival after the downfall of Melaka to Portuguese invasion. The Perak rulers had protected their royal palaces and strongholds by selecting their vantage points carefully, to detect the enemy approach from afar, in the 18th century, the Sultan had his first royal palace built beside the riverbank and named it 'Istana Sri Sayong'. Later the Perak monarch moved his palaces to Bukit Chandan. Figure 3 highlights the more distributive patterns of landmarks and open spaces along the Perak river, with clustering around the trading zones opposite artisanal centers of craftsmenship. The prominent landmarksw on the hill top for the royal family comprises of the complex of Istana Besar, Istana Kecil, Balai Mengadap, A Density of 5 to 7 units of houses per acre located to the southern side of the Perak River was found with spaces within easy access via foot path to the river transport to the hinterland . and these had become 
economic generators, which give rise to an urban population around the palace core. The public spaces within the royal complex were then used to hold, public events and traditional ceremonies. The overall approach in urban design recalls the use of nodes and landmarks of cultural and religious meaning and symbolism, yet integrated with principles that optimize climatic energies, the contributions of ecology and the impact on phenomenology. In Kuala Kangsar, the urban core was a simultaneous experience of place including that landscape, riverview and climatic factors and natural world elements which were perceived simultaneously and the elements of urban design of the tropical character can experienced socially, spiritually, physically and environmentally.



Figure 3. The linear urban core Layout of Bukit Chandan Kuala Kangsar (late 19th century)

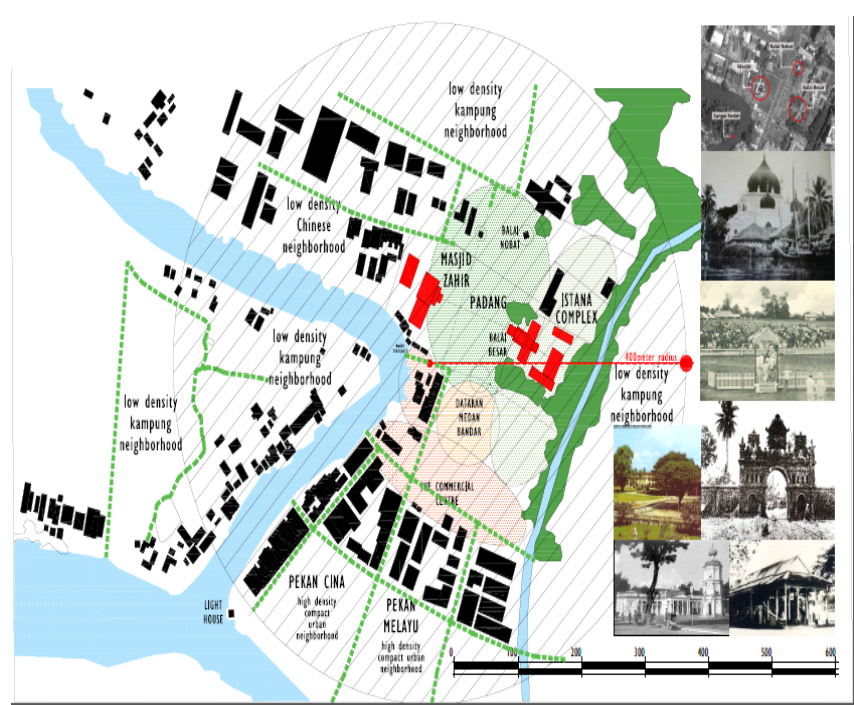

Figure 4. The clustered Alor Setar Urban core estimated layout ( early $19^{\text {th }}$ century)

\subsection{Alor Setar, Kedah}

Figure 4 shows the urban core estimation around the palatial BalaiBesar complex and field with the compact urban neighborhood to the south and west along the riverbank as part of commercial centre fronting the medan and padang and the low density kampung neighborhood beyond. Within $400 \mathrm{~m}$ radius of the centre of water transport mode, the jetty. The mosque straddles the river bank, while $18^{\text {th }}$ century patterns, which precedes Colonisation, shows there was an open space between the palace and the mosque. Both masjid and palace were sited and configured within an open green field or alun2/arena which then further symbolically charges the palaces to heighten the position of the monarch. Achmadi (2012) states how the Colonialists had often purposely built a road through such fields in order the break the symbolic and monumental enhancement of the royal symbol of the mosque, and palaces. In $18^{\text {th }}$ century AlorSetar ( Figure 4), one can clearly observe Masjid, the green field in between BalaiBesar and Istana Kuning, alun2 planked by the courthouse and the BalaiNobat; and commercial area/arena and Pekan China adjacement to the west along Sg. Kedah and Anak Bukit which also just behind Masjid Zahir; while the makam/graveyard diRaja pushed far toward inland, the eastern (Langgar) accessed by river.

\section{Discussions}

The pattern or morphology of these traditional 'estuary' centers reflect formal and geographical similarities with one another as they are located in adjacent to river banks or estuaries as centers of trade, communications and transport routes of the past. There was also the existence of wide fertile plains for agricultural efforts and these had further encouraged urban growth. Typically, such growth meant that the construction of a royal palace for the ruling class must be based on both security and accessibility. It was known that the royal institutions had exerted and considered key social and economic influence on urban layout and architectural form and elements. They became the 'agents' or instigator of change or development, and developments and settlements grew around the palace or centers of the ruling class. In their palatial layouts, it appears that the axial order was asserted to symbolise ' an ordered cosmos' and later these had 'urbanised' into complex structures, and these palaces and gardens continue to feature elements which reflect principles of climatic and environmental rationale in line with the tropical hot humid context. The resultant urbanscape and roof dominated forms were at once, sustainable and symbolic, representing meaning and links with its surrounding ecology.

Table 2 below reflect the observed characteristics of these centers against current criteria embodying sustainable principles of low carbon cities or green neighbourhoods at present time. All cases reflect a degree of organic planning with its core center often axially planned, surrounded by organically arrange building and spaces configuration. Yet there are inherent sustainable characteristics including the features surrounded by gardens and pathways which feature tree-line streets and tree canopies which completely shade the pathways

The table attempts to compare and discuss four determinants of sustainable urban form as extracted and gathered from Leadership in Energy and Environmental Design V4 Neighborhood Development by United Stated Green Building Council . The results show both traditional towns and its patterns reflect se veral criteria of low carbon cities or green neighbourhood (as outlined in Table 2 below). This study has identified five sustainable urban form that matched with LEED's criteria identified as 1) strategic location 2) optimum orientation 3) High permeability 4) increased levels of walkability and 5) Availability of landmark and strategic nodes. In all cases both cities reflect a degree of organic planning with its core center were axially planned, surrounded by organically arranged building and spaces configuration. Sustainable characteristics recalling the LEED's criteria including the features surrounded by gardens and pathways which feature tree-line streets and tree canopies which completely shade the pathways. 
Table 2. Sustainable criteria 4.0 (as per LEED Neighborhood Development version 4 versus the characteristics of Malay palatial 'urban' centres).

\begin{tabular}{|c|c|}
\hline $\begin{array}{l}\text { Urban Form } \\
\text { Sustainable elements (LEEDS V4) }\end{array}$ & $\begin{array}{l}\text { Kota Melaka and Kuala } \\
\text { Kangsar }\end{array}$ \\
\hline $\begin{array}{l}\text { Location: } \\
\text { Within and near existing communities, } \\
\text { proximity to public transit infrastruc- } \\
\text { ture, transit nodes and corridors }\end{array}$ & $\begin{array}{l}\text {-Within existing communities } \\
\text { of coastal fishing village by } \\
\text { the shore and the river bank } \\
\text { and within easy access to } \\
\text { water transport mode } \\
\text {-Density of } 5 \text { to } 7 \text { units of } \\
\text { houses per acre located with- } \\
\text { in easy access via foot path to } \\
\text { the jetty as the main transpor- } \\
\text { tation hub }\end{array}$ \\
\hline $\begin{array}{l}\text { Orientation: } \\
\text { Utilising the prevailing wind and } \\
\text { commanding view }\end{array}$ & $\begin{array}{l}\text { Openings to prevailing winds } \\
\text { to cool buildings }\end{array}$ \\
\hline $\begin{array}{l}\text { Permeability: } \\
\text { Pedestrian networks that encourage } \\
\text { walking and make places easier to } \\
\text { navigate through walkthrough struc- } \\
\text { tures and under elevated buildings } \\
\text { and through green pockets in be- } \\
\text { tween buildings. } \\
\text { - Includes all of the following at mini- } \\
\text { mum: } \\
\text { Building height for every } 3 \text { feet of } \\
\text { street width) along at least } 15 \% \text { of } \\
\text { street length. } \\
\text { Sidewalks along } 90 \% \text { of street length } \\
\text { (both sides of the street). }\end{array}$ & $\begin{array}{l}\text {-Network of footpaths } \\
\text { through intersection nodes } \\
\text { and elevated structures thus } \\
\text { enhance } \\
\text { community interaction and } \\
\text { healthy living } \\
\text {-Palace, mosques and mar- } \\
\text { ketplace as the common } \\
\text { landmark } \\
\text {-Traditional low rise building } \\
\text { complies with this require- } \\
\text { ment. }\end{array}$ \\
\hline $\begin{array}{l}\text { Walkability: } \\
\text {-Access to civic and public spaces } \\
\text { and transit route within walking } \\
\text { distance of } 400 \text { to } 800 \text { meters } \\
\text {-Treeline and shaded streets that } \\
\text { encourage walking through the } \\
\text { streets }\end{array}$ & $\begin{array}{l}\text {-Pedestrian and bullock cart } \\
\text { trails and series of loose fit } \\
\text { spaces that straddle within } \\
\text { the town and within } 400 \\
\text { meters along the waterfront } \\
\text {-Natural setting of the tropics } \\
\text { with shaded trees for pedes- } \\
\text { trians thus encourage walking }\end{array}$ \\
\hline $\begin{array}{l}\text { Landmark and nodes } \\
\text { Center nodes /urban image } \\
\text { as the public upon space }\end{array}$ & $\begin{array}{l}\text { The palace, mosque and pub- } \\
\text { lic building with the medan } \\
\text { or padang as an axis }\end{array}$ \\
\hline
\end{tabular}

Another shared sustainable characteristics include the padang or medan, an open field located in front of the sultan's palace that act as the administrative hub for the Malay society. The royal court is characteristically wide and turfed, surrounded by huge shady trees and has an overriding quality that acts as an outdoor room and an enclosed square. The semi-enclosure space is visually strengthened by administrative buildings or a palace and rows of large matured trees that act as continuous features linking one end to another. In term of orientation, the location that is located in front of coastal area helps to prevailing winds to cool buildings.

Padang and series of loose fit spaces along the main route inside both cities not only enhance walkability but at the same time maintained the biodiversity through moderating the extreme tropical weather. At the padang and along the loose fit spaces are where the public came to watch buffalo fights, play sepak raga (a traditional Malay game) and get involve in other informal and formal activities such as sultan's coronation and birthday celebrations that were purposely organized for the public (Noor Fazamimah, 2007; Wan Zakri, 2008; Nor Zalina and Ismail, 2008 ). In such instances, the true civic centre of the town is the padang (Nor Zalina and Ismail, 2008) and regular assemblages were held at the courtyard or medan, particularly the assembled crowds of the Friday noon prayer in the main mosque.

The late 1800 s and early 1900 s was for a time of both physical, political and ideological transformation in the region with consequent impact on urban configurations which refer to the dynamics of modern cities and the ruling class of the Malay states. Under the colonial rule, socio-economic changes had occurred on both sides of the Straits of Melaka. The Malay socio-political institutions were developed and urban layout was reshaped through a newly imposed political economy by the ingratiation of the Colonising powers. The position and development of palatial architecture and its urbanized spaces had reflected how the rulers still held political power, but was slowly undergoing drastic changes in terms of military or economic power. Such urban centers still symbolically and spatially reflected the spiritual and cultural meaning of the localities, yet slowly other communities from external origins started revolutionising the whole society including its political and religious systems. Historically, an active interaction occurred between the local and external communities, yet due to their shared traditions and cultural values, and political links, inter-marriages and trade occurred frequently.

Even though from the comparison which help to reconstruct the past and from which emerges similarities and differences between the three cities, the study managed to come out with a generalisation. The study reveals that the sustainability criteria of the three cities can be considered based on the following relevance:

i. $\quad$ Provide thermally comfortable environment

ii. Urban form that support the social life of residents Numerous platforms for daily activities symbolize the culture and identity of cities and its people.

In all three cases, the siting of palaces was an environmentally significant and crucial decision of the times, and many were located adjacent to rivers and enjoy the cooling effect of water bodies with the comforting panoramic view. Extending from the palace grounds are roads shaded completely by shady vegetations .Spatially there was consistently, a fusion of private and public and extending into a kind of public urban space, in terms of 'core and transition', revealing a hierarchy of space in the urban core that was reflective of a social order and structure ; The functionality of space is not merely in terms of architecture and everyday requirements but including ritual and orientation of space, and the zones of public and private spaces. Some of these climatic features can be summarised as :

1.Kuala Kangsar's palace is a fragmented form with insertion and wind slits for ventilation rather than compact forms and these is known to facilitate natural ventilation nad passive cooling in the tropics through the spaces

2. The Melaka palace and Alor Setar palace has a tiered form of the roof, reflect a synthesis with site and optimizing both building and locations general climatic feature to maximise its capacity of wind driven ventilation and thermal stratification through stack effect in the tropics.

A critical assessment of the urban spaces and core layout is estimated from records and documents from the 15th century to 19th century is studied. The Malay civilization is known for its economic activities surrounding rivers which thrived from the 15 th to late 19th century and for symbolically-charged fields between the palace and the mosque. Some researchers (Evers, 2000) have argued although Malay kingdoms do not have a city in the normal sense of word, their sites of palaces and gardens are actually similar urban spaces with, the palatial complexes can be argued as a form of urban architecture of its time. Before the Colonialist inserted a road to break the urban 'padang' in early 20th centuries, many towns such as Kedah and Kelantan, during the 18th to 19th century, had the river, mosque and Audience hall (Balai Besar) as one continous symbolically -charged public zone with shaded extensions facing each other. These held functions related to government, and were centers of quasi-urban life exhibiting traditional archetypical forms of open-air squares and shaded porticos courtyards. The urban scape was a range of profiles of porticos 
and projections, and the city's urban scape depicted a series of shaded forms - rather than flat facades- with the occasional open air pavilions. In the Melakan empire - commercial units borders the bridge and had functioned activated nodes near river connections, with the bridge of the 16th century ( which had been eventually burnt down by the invading Portuguese) as one of the active centers of trade and overlooking the river. A 'shade-to-void' analysis can be done to further study the prevalence of such shaded public spaces including the 'waqf' structures and the frontages of 'aristocratic houses' which saw such public spaces become the extension of open spaces -similar to how an an overlooking 'serambi' act as a community focus in the tropical settlements.

Royal courts were locally known as the medan, located in front of the sultan's palace and in most cases, these were, in fact the hub of local life. A common character of the royal court was its wide, turfed lawns and its general outdoor spaces which were surrounded by huge shady trees. These have an overriding quality of its spatial type is where the royal court acts as an outdoor room and an enclosed square. The semi enclosure of its space was strengthened by administrative buildings or a palace and rows of large matured trees that act as continuous features linking one end to another. Large trees are natural elements that create shaded zones and natural boundaries extending from the properties and the historical buildings in the tropical Asia should be depicted as extending urban spaces and shaded zones with the presence of such large trees. Trees, under the tropical environment, are crucial and must be considered as compulsory or prerequisite urban elements assembled that must surround urban spaces and be preserved and maintained as these are crucial in causing urban experiences in the tropical city. By grouping these natural elements and their properties, the tropical city takes on a unified form. The emergence of native trees, shades and wildlife must be seen as support to the notion of the city. Trees msut be increasingly recognized as having a role in the preservation of the natural and extensions of built properties which are capable of increasing the sustainable credentials and enhancing the authenticity of the urban fabric. Large trees are natural elements that create shaded zones and natural boundaries extending from buildings. Trees, under the tropical environment, must be considered as urban elements assembled around urban spaces and causing urban experiences in the tropical city. The strong visual structure of the studied sites and reconstructions of these urban cores suggest how they were variations of compositions of natural elements and architectural composition represents a systemic form with principles that hold the urban space together maintaining a tremendous sense of enclosure and completeness while at the same time, achieving comfort in the outdoors.

The morphologies imply that such three dimensional configuration interspersing green and physical elements in urban space are crucial for sustainable targets and they should not be merely seen as symbolic markers in an open ground to enclose and symbolically charged an urban void for viewers. Key public activities in the past under such tropical context were outdoors including commercial and recreational activities which had normally taken place around such spaces and including nearby commercial centre with market area -the medan and the padang ; suggesting that the comfort conditions within the urban core were optimized during such times. The trading activities of the market places were conducted in the morning and recreational were ones held in the evening. The padang had been the setting for outdoor activities such as recreation, business transaction and religious events, and the public had often congregated to watch buffalo fights, play 'sepak raga' (a traditional Malay game) and get involve in other informal and formal activities such as sultan's coronation and birthday celebrations that were purposely organized for the public (Noor Fazamimah, 2007; Wan Zakri, 2008). In such instances, the true civic centre of the town is the padang (Nor Zalina and Ismail, 2008) and regular assemblages were held there particularly the assembled crowds of the Friday noon prayer in the main mosque.

In these early urban patterns, urban streets seem to overlap and diffused organically into the open 'padang or medan'. They did not end at the edge of the open space but legibly continues into it. In certain cases, open pavilions had symbolically enhanced the open spaces. The blending between the streets and such open spaces often served as a gateway to events whenever there were special occasions but during normal days it serve as a gateway to quality sensory experience of the urban core. The urban core and spatial layout of these sites reflects certain fundamental principles of environmental design in the tropics which in turn suggest the crucial role of extensions of buildings, orientation with respect to the river, and shaded elements, including large trees. The study suggests how past urban cores demonstrate a degree of fragmented and organic order with their massing and spatial layout optimized and arranged in order to promote ventilation and airflow under hot humid conditions. Principles of sustainable urbanism in the tropics were implemented include a degree of organic planning which are crucial to allow breathability due to the multidirection of tropical winds - attuned to the hot and humid nature of the tropical conditions, with public areas open to adjacent water bodies and vegetation. The gardens and pathways feature tree-line streets and tree canopies which shade the pathways and pavement surfaces. In these palatial structures and its urban layouts, it appears that axial forms of planning are asserted only when necessary.

\section{Conclusion}

Overall, this study offer valuable insights into past patterns and configurations which reflect an optimum state of urban sustainability that can eventually be used as templates for future generation. It has demonstrated how such early centers are distinctive and synthesise a sense of place of its own and their individual urban character are determined in large measures by pattern created by the alternation of structures and voids that is of buildings and spaces in between. The case of Melaka, Alor Setar and Kuala Kangsar demonstrates past patterns that commensurate with the sustainable set of criteria.

The urban core patterns and configurations of these early sites and cities reflects fundamental principles in the tropics which necessitate shaded elements, large trees and a degree of fragmented and organic order in terms of massing and layout in order to promote breathability of urban form, ventilation and airflow infusion from nearby rivers, oceans or water bodies hrough a masterplan under hot humid conditions. Principles of sustainable urbanism inclusive of criteria such as density and permeability should be further measured to verify such key objective measures and benchmarks This suggest that the present implementation of criteria in sustainable cities must again witness the re-emergence in the vernacular in order to drive, sustain and highlight strategies that can fulfill the rising agenda of sustainability and sustainable development in different cultures and communities Presently, there are increasing aspects of sustainability linked to the past planning of the built environment, as Alexander, (1977) had foreseen the need for cities to utilize models of the past as they ".... must recapture the process by which cities develop organically. in order 'to create new theoretical framework, to remedy the defects of cities today'. 


\section{Acknowledgement}

The authors would like to express their sincere gratitude to the Ministry of Higher Education Malaysia (MOHE) in the support of this research. This research is funded by the Transdisciplinary Research Grant Scheme (TRGS) for research project code TRGS16-03-001-0001.

\section{References}

[1] Brown, M. G. (1999). Charter of the New Urbanism, Congress of the New Urbanism, Edited by Michael Leccese and Kathleen McCormick, McGraw-Hill, 180 pages.

[2] Samsuddin, N. (2014). The Physical Design Atrributes of Traditional Malay Kampung in Kampung Tanjung Bunut, Kuala Terengnnau, IGCESH2014, Universiti Teknologi Malaysia, Johor Bahru, Malaysia 19-21 August 2014

[3] Kusno, (2010). The Appearances of Memory: Mnemonic Practices of Architecture and Urban Form in Indonesia, Duke University Press, 4 Feb 2010

[4] Brown, C. (1976), Sejarah Melayu, The Malay Annals, Oup, Hong Kong 1976, p. 151

[5] Nor Zalina, H. and Ismail, S. (2008). Role and Fate of Padang in Malaysian Historical Cities. Proceedings of the 5th GreAsian Street Symposium. 5-7 December. National University of Singapore, Singapore.

[6] Noor Fazamimah, M.A. (2007). Role of Cultural Landscape in Improving the Identity of the Kuala Terengganu Town Centre as a Malay Historic Town. Universiti Teknologi Malaysia, Faculty of Built Environment.

[7] Wan Mohd Zakri, W.A. (2008). Appropriate Urban Public Open Space. Unpublished PhD Thesis. Johor: Universiti Teknologi Malaysia.

[8] Hagan, Susannah.(2014),Ecological Urbanism and the Nature of the city, Routledge, London.

[9] Evers, H. and Korff, R. (2000). Southeast Asian Urbanism: The Meaning of Power and Social Space. Munster: LIT Verlag.

[10] Amoroso, D. (2014). Traditionalism and Ascendency of the Malay ruling class in Colonial Malaya (Singapore: National University of Singapore Press).

[11] LEED v4 Edition (2014). LEED Reference Guide for Neighborhood Development, U.S. Green Building Council;

[12] Harry Benda and John Larkin (eds.), The World of S. East Asia, Selected Historical Readings, Harper and Row Limited, N. York, 1967, p. 16.

[13] Sir Carnac Temple, The Itenary of LudocivoVarthema of Bologna from 1502 to 1506, The Arganout Press, London, 1928, p.84.

[14] Alexander, Christopher Sara Ishikawa, Murray Silverstein, 1977, A Pattern Language: Towns, Buildings, Construction. Oxford University Press.

[15] Carmona, Mathew, 2010, Public Places, Urban spaces- the Dimensions of Urban Design, Routledge. 